\title{
Lawrence H. Cohn, MD (1937-2016)
}

\author{
Delos M. Cosgrove, MD
}

\author{
From the Department of Thoracic and Cardiovascular Surgery, Cleveland Clinic, Cleveland, Ohio. \\ Disclosures: Author has nothing to disclose with regard to commercial support. \\ Received for publication Feb 17, 2016; accepted for publication Feb 19, 2016. \\ Address for reprints: Delos M. Cosgrove, MD, Department of Thoracic and Cardiovascular Surgery, Cleveland \\ Clinic, 9500 Euclid Ave, Cleveland, OH 44106 (E-mail: cosgrod@ccf.org). \\ J Thorac Cardiovasc Surg 2016;151:1227-9 \\ $0022-5223 / \$ 36.00$ \\ Copyright $(C) 2016$ by The American Association for Thoracic Surgery \\ http://dx.doi.org/10.1016/j.jtcvs.2016.02.076
}

Lawrence Harvey Cohn, MD, enjoyed one of the most remarkable careers in thoracic and cardiovascular surgery. He was a leading figure in our specialty from the end of the pioneering age of open heart techniques through to the present day, remaining a vital force in the profession right up to his death from stroke at the age of $78 .^{1}$ Dr Cohn was a renowned clinician, investigator, and teacher. Over the course of a life well lived, he earned the gratitude of patients, the admiration of his peers, and the warm regard of all who were privileged to call him friend.

He graduated from the University of California at Berkeley in 1958, and received his medical doctorate from the Stanford University School of Medicine in 1962 (Lawrence H. Cohn, MD, curriculum vitae). He was an intern and junior assistant resident in General Surgery at Boston City Harvard from 1962 to 1964, and spent the following 2 years as surgeon, United States Public Health Service, Surgical Associate, Clinic of Surgery, in the National Heart Institute in Bethesda, Maryland (Lawrence H. Cohn, MD, curriculum vitae). In 1966, he went to the University of California, San Francisco, for a residency in Thoracic Surgery and returned to Stanford from 1969 to 1971 where he was resident and chief resident of Cardiothoracic Surgery (Lawrence H. Cohn, MD, curriculum vitae).

In 1971, Dr Cohn began a long and successful career as a surgeon at the Brigham and Women's Hospital and educator as a professor of surgery at Harvard Medical School (Lawrence H. Cohn, MD, curriculum vitae). He was appointed chief of Cardiac Surgery at the Brigham in 1987, and director of the Cardiothoracic Residency program that same year (Lawrence H. Cohn, MD, curriculum vitae). As a surgeon, he performed more than $11,400^{2}$ operations and trained more than 150 residents and fellows. ${ }^{3}$ In 2000 was awarded the Virginia and James Hubbard Chair in Cardiac Surgery, the first endowed Chair in Cardiac Surgery at Harvard Medical School. ${ }^{2}$

He published more than 470 scientific papers, and edited, authored or co-authored 105 book chapters and 12 books, including the second, third and fourth editions of the essential textbook Cardiac Surgery in the Adult. Over the years, he delivered more than 750 lectures worldwide. ${ }^{2}$

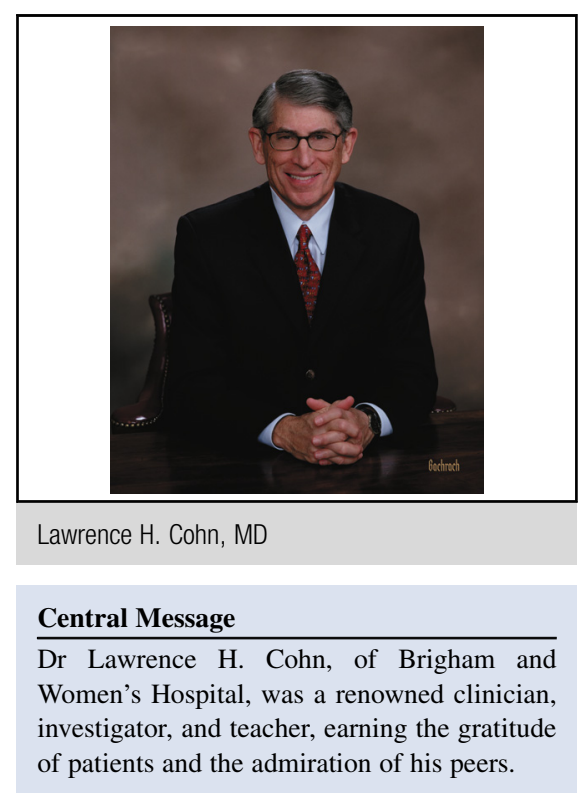

Dr Cohn's role as a researcher was also an essential part of his professional career. He served as director of the Cardiac Surgery Laboratory at the Brigham and Harvard Medical School from 1971 to $2001 .^{2}$ As a researcher, he investigated all aspects of reconstructive valve surgery, adult congenital heart surgery, and thoracic aortic pathology. ${ }^{2}$ He led landmark studies of coronary and mitral valve outcomes, and in 1997 he published the results of a series of valve surgeries performed through a partial sternotomy that established the comparable viability of minimally invasive valve replacement and repair. ${ }^{4}$

Lawrence H. Cohn was born in San Francisco, California. His father was a survivor of the San Francisco earthquake of 1905, and a successful dealer of building supplies. His mother was a concert pianist, and Larry studied piano himself until age 11 , performing one successful recital before retiring from the instrument. As a young man, he worked in his father's business, absorbing his father's work ethic and gaining people skills that would serve him well later in life.

At the academically challenging Lowell High School, he earned high honors and served as editor of the school paper. He participated in basketball, track, and other athletics, and went on to become a lifelong sports enthusiast, playing tennis and golf right up to his death. ${ }^{1,5}$ During a busy period of high school, his principal advised him, "You have a lot of things to do: Budget your time." It was an admonition he came to live by. 
As an undergraduate at the University of California at Berkeley, he lived in a fraternity house and majored in American history. While contemplating his future, an older relative convinced the young man that he would be unhappy in business, and as a result Larry began taking pre-med courses to investigate a career as a physician. His first A in freshman chemistry sealed his new intention to go to medical school. Before his graduation in 1958, his family dermatologist (Eugene Farber, MD, brother of Sidney Farber, MD, founder of the Dana-Farber Cancer Institute at Brigham) convinced him to apply to Stanford University School of Medicine.

Originally inclined to become a medical doctor, he was fortunate to encounter powerful surgical role models early in his studies. These included Roy Cohn, MD, and future heart-transplant pioneer Norman Shumway, MD, then just arrived at Stanford. A surgical externship at Mt. Zion Hospital in San Francisco stoked his interest further. When he told his professor of medicine that he wanted to go into "something where I could really do something for people," the professor replied, "You need to go into surgery" - advice Larry happily followed. ${ }^{5}$

Larry first met his future wife, Roberta, when he was 12 and she was 11. Larry took Roberta to her first dance, and they dated until he went away to college. They married in 1960, and their first child was born in $1963 .{ }^{1}$

As a medical school senior, he began hearing more about the developing field of cardiac surgery, and was particularly intrigued by Dr Shumway's experiments in canine heart transplantation. He was invited to do a subinternship with Dr Shumway and another cardiac surgery pioneer, then-resident Richard Lower, MD. He recalled being "mesmerized" by the experience and not leaving the hospital for 8 days. Despite his enthusiasm for the work, Dr Shumway advised him to leave Stanford, travel, and get trained in general surgery before coming back. $\mathrm{He}$ graduated Alpha Omega Alpha, and followed Dr Shumway's suggestion. ${ }^{4}$

In 1964, Dr Cohn won a fellowship in the National Heart Institute with pioneering valve surgeon Glenn Morrow, MD. His mentors at the National Heart Institute included Gene Braunwald, MD, with whom he worked 6 months in the catheterization lab-deepening his own knowledge of heart disease and cardiac physiology. He also did original investigations during this fellowship.

Dr Cohn took his young family back west in 1966, where he did a residency in thoracic surgery at the University of California, San Francisco. There, he gained experience in general surgery and especially vascular surgery. This experience included doing 5 carotid endarterectomies in one day with Jack Wylie, MD, the developer of the procedure. ${ }^{5}$ In 1969, he rejoined his former mentor Dr Shumway at Stanford, where he became chief resident in cardiovascular surgery (Lawrence H. Cohn, MD, curriculum vitae).
At Stanford, he participated in 1000 operations a year, acting as primary surgeon in 500. The Stanford program was getting national attention, and in 1970, Dr Cohn traveled to Boston to give a presentation on the team's work on aortic valve replacement.

At that time, Stanford had the lowest cardiac surgery mortality in the country. Brigham's (then Peter Brent Brigham Hospital) chair of Cardiac Surgery, John Collins, $\mathrm{MD}$, was ambitious to raise the quality of his program. Dr Collins and Surgeon-in-Chief Francis Moore, MD, recruited Dr Cohn right out of residency, and gave the young surgeon an unprecedented mandate: To transform Brigham's cardiac surgery program based on the Stanford model. "That's all I needed to hear," Dr Cohn recalled. ${ }^{2,5}$ Dr Moore later described Dr Cohn as his "finest recruit.".

After first conferring with the nurses, Dr Cohn overhauled Brigham's operating room protocol. He changed instruments and sutures and replaced coronary perfusion with local cardiac hypothermia. ${ }^{5} \mathrm{He}$ was made director of the Cardiac Surgery Laboratory at Harvard Medical School in 1971 (serving in that capacity until 2001) and was promoted to Professor of Surgery in $1980 .^{2}$ In 1985, he and Dr Collins performed New England's first heart transplantation at the Brigham. ${ }^{6}$ When Dr Collins stepped down as chair of Cardiac Surgery in 1987, Dr Cohn was appointed in his place.

Over the course of his career, Dr Cohn mastered the full range of thoracic and cardiovascular procedures and techniques. He was an outstanding technician, with a special focus on valve surgery and mitral valve repair. $\mathrm{He}$ went on to do approximately 300 valve operations a year. ${ }^{5}$ He led exhaustive studies of prosthetic and bioprosthetic valves and valve repair, deepening our knowledge of the properties and effectiveness of these treatments.

His impact as a teacher equaled if not surpassed his clinical achievements. At least 30 of his 150 trainees have gone on to lead divisions and departments at top institutions. In 2012, Dr Cohn proudly noted that 6 members of Cleveland Clinic's Thoracic and Cardiovascular Surgery staff were trained at Brigham. ${ }^{2}$

In the 1990s, the practice of surgery was being reshaped by the development of minimally invasive techniques. Orthopedics, gastrointestinal surgery, and urological surgery were achieving comparable results and shorter hospital stays for patients through smaller incisions. ${ }^{2}$

In 1997, Dr Cohn published the results of minimally invasive aortic or mitral valve replacement or repair in 84 patients - comparing the outcomes of 50 of these patients to 50 patients who had an open sternotomy. He showed that minimally invasive cardiac valve surgery improves patient satisfaction while reducing costs of cardiac valve replacement and repair compared to the open procedure. ${ }^{4}$

His enthusiasm for innovation was balanced by a strong commitment to evidence, which led him to review and 
re-review all his findings. ${ }^{2}$ The breadth of his interests is reflected in the range of topics of his published works. He was on the editorial boards of 14 journals $^{8}$ and became the eighth editor of The Journal of Thoracic and Cardiovascular Surgery in 2007, serving until 2014.9

Dr Cohn held office in The American Board of Thoracic Surgery and the American College of Cardiology. He was president of The American Association for Thoracic Surgery, president of the American College of Chest Physicians, president of the Thoracic Surgery Foundation for Research and Education, and chairman of the Board of the National Library of Medicine. He belonged to 20 other professional organizations, with honorary membership in 4 international groups. ${ }^{8}$

Dr Cohn was collegial to the core, and forged many friendships inside and outside the profession. A keen conversationalist, he was quick with appropriate anecdotes and wry remarks. Despite his busy professional schedule, he and Roberta found time to travel widely, visiting every continent on Earth but Antarctica. ${ }^{10}$ In his local community, he was an overseer for the Boston Symphony Orchestra, on the board of the Boys and Girls Clubs of Boston, and involved with the Museum of Fine Arts. ${ }^{1}$ He collected antique books related to cardiovascular medicine, and, in 2008, he donated them to Brigham, where they now constitute the Cohn Library.

His life was full of well-deserved honors. These include a Doctor Honorus Causa from the University of Paris (1992), an honorary Masters of Medicine from Harvard (1989), and the Distinguished Alumni Award from the University of California at Berkley (1998). He was also the recipient of the Paul Dudley White Award, the highest award given by the American Heart Association. ${ }^{5}$

He was not only a clinician, researcher, and educator but also a cardiac surgery patient. There was heart disease in his family, and in 1985, Dr Cohn heard a precordial murmur in his own heart. This led to a minimally invasive aortic valve replacement in 1997 . The experience of being a patient reinforced his deeply humanistic view of medicine. "It made me a better physician," he said. ${ }^{5}$

In addition to his wife, he leaves 2 daughters, Leslie Bernstein of Newton, Massachusetts, and Jennifer of San
Francisco, California; 2 granddaughters, Carly and Rachel; a grandson, Cameron; and son-in-law Stephen Bernstein. ${ }^{1}$

Dr Cohn had a deep appreciation for the history of thoracic and cardiovascular surgery. He surely recognized his towering place in that legacy. He shaped one of the finest thoracic and cardiovascular surgery programs in the world, and made indelible contributions to the specialty through the most dynamic years of its growth and development.

It is not in the nature of a good surgeon to be perfectly satisfied, but Dr Cohn deserved to take pride in his accomplishments. He did his best for patients, trainees, and the institution he served, and his best was beyond good. His name will always be associated with greatness in thoracic and cardiovascular surgery and his achievements should inspire all those who follow this rigorous profession.

\section{References}

1. Marquard B. Dr Lawrence H. Cohn, 78; 'master of masters' in cardiac surgery. The Boston Globe. January 12, 2016. Available at: https://www.bostonglobe com/metro/2016/01/11/lawrence-cohn-master-masters-cardiac-surgery-dies/dKfz 9GXF74f9eEangD5t1K/story.html. Accessed March 14, 2016.

2. Tishler P. Lawrence Cohn [transcript]. Brigham and Woman's Hospital. June 2012. Available at: http://videocenter.brighamandwomens.org/files/dmfile/ Cohn_Lawrence.pdf. Accessed March 14, 2016.

3. Ikonomidis J. Historical perspectives of The American Association for Thoracic Surgery: Lawrence H. Cohn. J Thoracic Cardiovasc Surg. 2014;148:1158-61.

4. Cohn LH, Adams DH, Couper GS, Bichell DP, Rosborough DM, Sears SP, Aranki SF. Minimally invasive cardiac valve surgery improves patient satisfaction while reducing costs of cardiac valve replacement and repair. Ann Surg. 1997;226:421-6.

5. Roberts WC. Lawrence Harvey Cohn, MD: a conversation with the editor. Am J Cardiol. 2006;97:929-42.

6. Brigham and Women's Hospital. Milestones in cardiac surgery. Available at: http://www.brighamandwomens.org/Departments_and_Services/surgery/services/ cardiacsurgery/milestones.aspx?sub=0. Accessed March 14, 2016.

7. Brigham and Woman's Hospital. Obituary: John "Jack" Collins, MD, heart transplant pioneer, 76. BWH Bulletin. March 19, 2010. Available at: http:// www.brighamandwomens.org/about_bwh/publicaffairs/news/publications/dis playbulletin.aspx?articleid=4804. Accessed March 14, 2016.

8. Partners HealthCare. Lawrence Cohn, MD. Available at: https://symposium connectedhealth.org/speakers/lawrence-cohn-md. Accessed March 14, 2016.

9. Elsevier. The Journal of Thoracic and Cardiovascular Surgery editorial board. Available at: http://www.journals.elsevier.com/journal-of-thoracic-and-cardio vascular-surgery/editorial-board/. Accessed March 14, 2016.

10. Harvard TH. Chan School of Public Health. Educating and informing grea numbers of people. Available at: http://www.hsph.harvard.edu/campaign/ educate-and-inform/. Accessed March 14, 2016. 